\title{
Ascorbic acid level of Belgian apple genetic resources
}

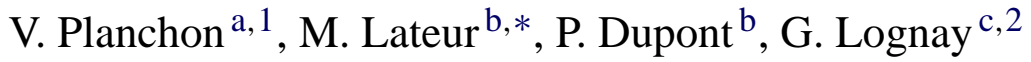

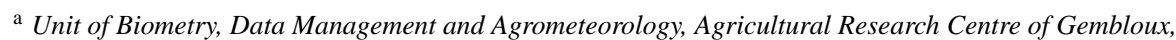 \\ Rue de Liroux, 9-B-5030 Gembloux, Belgium \\ ${ }^{\mathrm{b}}$ Department of Biological Control and Plant Genetic Resources, Agricultural Research Centre of Gembloux, \\ Chemin de Liroux, 4-B-5030 Gembloux, Belgium \\ ${ }^{c}$ Unit of General and Organic Chemistry, Gembloux Agricultural University, Passage des Déportés, \\ 2-B-5030 Gembloux, Belgium
}

Accepted 11 August 2003

\begin{abstract}
With the help of the public, a wide collection of old apple cultivars (cvs) was established progressively at our Department from 1975 onwards. Currently, more than 1400 apple accessions are being maintained and three quarters of them are subjected to field evaluation for disease resistance and agronomic characters. This paper presents results of the ascorbic acid (Vitamin C) contents of old cvs combining interesting disease resistance and agronomic features in order to promote them as cvs adapted to production systems which are more environmentally friendly or to be used as parents in breeding programmes. First, a methodological study shows the importance of the variability of ascorbic acid content depending on fruit position in the trees, fruit size, fruit skin colour and maturity stage. Statistical analyses show that the sample size of six fruits per cv is sufficient to detect a difference of $20 \%$ between cvs. Old apple cvs such as Grenadier ${ }^{\mathrm{RGF}}$, Transparente de Croncels, Bramley's Seedling, Reinette des Capucins, Reinette Libotte and Reinette de Waleffe contain three and seven times more ascorbic acid than the commercial cvs Gala and Elstar, respectively. The paper highlights the need to evaluate the rich potential in our genetic resources.
\end{abstract}

(C) 2003 Elsevier B.V. All rights reserved.

Keywords: Ascorbic acid; Genetic resources; Apple; Maturity

* Corresponding author. Tel.: +32-81-62-03-33; fax: +32-81-62-03-49.

E-mail addresses: planchon@cra.wallonie.be (V. Planchon), lateur@cra.wallonie.be (M. Lateur), lognay.g@fsagx.ac.be (G. Lognay).

1 Tel.: +32-81-62-65-74; fax: +32-81-62-65-59.

2 Tel.: +32-81-62-22-90; fax: +32-81-62-22-27. 


\section{Introduction}

In a research project on "Fruit Tree Genetic Resources (FTGR) and Disease Resistance", more than 1400 old apple cultivars (cvs) formerly grown in Belgium have been collected, with the help of the public. The initial intention was to conserve this genetic diversity and to screen the material for disease resistance and other characters of agronomic interest. The aim was to use the better performing cvs either for the nursery trade, for fruit growers, for fruit processing industries or as breeding parents (Populer et al., 1998; Lateur, 2000).

Within our ongoing studies, a project was initiated to characterise the chemical composition of old apple varieties, the overall aims being:

- to promote high-quality products without pesticide residues and with interesting nutritional properties;

- to develop cvs with recognised dietetic qualities, in collaboration with commercial fruit growers using the Integrated Fruit Production System or Organic Production System;

- to encourage the exploitation of cvs chosen for their high ascorbic acid level that could be of interest to fruit processing industries. Apart from its vitamin properties, ascorbic acid is a powerful and natural oxygen scavenger (anti-oxidant) that prevents fruit browning and contributes towards better fruit product utilisation and preservation.

According to Schuphan (1956), Mapson (1970), and Fisher (1999), apple contains 2$30 \mathrm{mg}$ ascorbic acid per $100 \mathrm{~g}$, depending on the cv. This concentration decreases progressively from the peel to the core of the fruit (Ulrich and Delaporte, 1970; Machlin, 1991) and there is twice as much ascorbic acid in the red part of apple peel than in the green part (Tavernier and Jacquin, 1946). Vitamin C is present in two forms in applesascorbic acid, and its oxidised form, dehydroascorbic acid (Davies et al., 1991). The total level of the two forms is constant per unit weight during growth, although the ascorbic acid/dehydroascorbic acid ratio increases to at least 95/5 at fruit maturity (Mapson, 1970). The variability of ascorbic acid levels between fruits of a same cv and between years can be very high (Trzcinski and Bouckoms, 1973; Trzcinski and Vandermeir, 1974; Delmotte, 1984).

During conservation, the loss of ascorbic acid is influenced by $\mathrm{cv}$ factors and storage conditions such as temperature, storage duration and atmosphere (Mapson, 1970; Delaporte, 1971). Numerous analytical techniques have been developed to measure ascorbic acid and dehydroascorbic acid. Currently, due to its sensitivity, repeatability and selectivity, high performance liquid chromatography (HPLC) with UV or electrochemical detection is generally used (Wimalasiri and Wills, 1983; Barthelemy, 1996).

The paper first describes a simple HPLC procedure for the measurement of ascorbic acid that allows rapid and repeatable measurements on a single fruit. The main goal of the study was to compare the ascorbic acid concentration in different apple varieties. Nevertheless, due to the variability of ascorbic content in apple, it was important to study the influence of different factors such as fruit size, peel fruit colour and fruit position in the tree in order to define a reliable sampling methodology. The paper then presents the results obtained for ascorbic acid contents and for global fruit composition parameters which determine the fruit organoleptic quality (maturity index (MI), sugar, acidity, dry matter (DM)) of a sample of Belgian apple genetic resources. 


\section{Material and methods}

\subsection{Preliminary studies}

The year before the main study, preliminary studies (year 1998) were done in order to evaluate the importance of some factors that are known to influence ascorbic acid determinations, including:

(a) the sample preparation and analytical procedures (HPLC);

(b) the variability of ascorbic acid content from one fruit to another on the same tree (effect of diameter, coloration and position) and the variability of ascorbic acid content between trees in the same orchard;

(c) the variability of ascorbic acid content from one $\mathrm{cv}$ to another.

These studies allowed us to estimate the sample size needed for convenient repeatability for comparison purposes. Variability from one year to another, localisation in the country and weather conditions are factors that were not taken into account in the present work.

The following tests were undertaken:

(a) To evaluate the variability of the analytical procedure, double blind tests were performed to determine ascorbic acid content in composite samples of three cvs (Reinette Hernaut $^{\mathrm{RGF}}$, Président Roulin ${ }^{\mathrm{RGF}}$, Grenadier $^{\mathrm{RGF}}$ ); "RGF" is the acronym for Ressources Génétiques Fruitières and corresponds to the French acronym FTGR.

(b) To check the influence of size/colour/position factors on the same tree and variability between trees, determinations of ascorbic acid were done for $40 \times 2$ Jonagold apples (Dacosta mutant): (a) diameter of 70 and $85 \mathrm{~mm}$, (b) coloured (red peel) or non-coloured (green peel), (c) exposed to sun or in the shade of the tree. Five fruits were sampled for each factor combination on two different trees in the same orchard.

(c) To evaluate the variability of ascorbic acid content from one cv to another, a comparison of ascorbic acid content was made between six old cvs: Grenadier ${ }^{\mathrm{RGF}}$, Bramley Seedling, Court-Pendu Gris, Reinette de Blenheim ${ }^{\mathrm{RGF}}$, Reinette Hernaut ${ }^{\mathrm{RGF}}$ and Reinette de Waleffe. Twelve sunny position/coloured apples of these six cvs were picked from two or three apple trees. Sugars and $\mathrm{pH}$ were also analysed.

\subsection{Main study}

All methods used to evaluate the collection of FTGR have been described previously (Lateur and Populer, 1996; Populer et al., 1998). The common criteria for the selection of cvs were (in order of importance) durable disease resistance or very low disease susceptibility, high organoleptic quality, good yield, good fruit keeping on the tree, long fruit storage life and resistance to fruit rotting agents. Fruit size and visual characteristics were also taken into account.

Twelve old cvs were reintroduced into the nursery trade by the Department of Biological Control and Plant Genetic Resources: Cwastresse Double ${ }^{\mathrm{RGF}}$, Godivert ${ }^{\mathrm{RGF}}$, Grenadier ${ }^{\mathrm{RGF}}$, Gris Braibant ${ }^{\mathrm{RGF}}$, Joseph Musch ${ }^{\mathrm{RGF}}$, La Paix ${ }^{\mathrm{RGF}}$, Président Roulin ${ }^{\mathrm{RGF}}$, Radoux ${ }^{\mathrm{RGF}}$, Reinette de Blenheim ${ }^{\mathrm{RGF}}$, Reinette Evagil ${ }^{\mathrm{RGF}}$, Reinette Hernaut ${ }^{\mathrm{RGF}}$ and Président Van 
Dievoet ${ }^{\mathrm{RGF}}$. The acronym "RGF" is used after each cv reintroduced by the Department via the nursery trade. Unfortunately, no fruit of the cvs Grenadier ${ }^{\mathrm{RGF}}$ and Reinette Hernaut ${ }^{\mathrm{RGF}}$ were available for the main study (year 1999) because their maturity stage was too advanced for tests. Twenty other cvs, reported in the literature for their high ascorbic acid content and/or for having some interesting traits were also investigated. All cvs were grafted on M9 rootstock and planted at $4 \mathrm{~m} \times 3 \mathrm{~m}$ in the 1979-1983 period. Orchards were kept free of any pesticide treatment. For cvs Bramley Seedling, Reinette Etoilée and Reinette des Capucins, two fruit sets were picked at two different maturity indices. For comparative purposes, five commercial cvs-Schone van Boskoop, Elstar, Gala, Golden Delicious and Jonagold-were integrated in the study. For each cv, six sunny position/coloured fruits were picked at a maturity stage defined during a previous evaluation period. All fruits are picked in the germplasm of the Department of Biological Control and Plant Genetic Resources.

\subsection{HPLC determination of ascorbic acid}

\subsubsection{Sample preparation}

The apples were cut in two, along a longitudinal axis. Immediately, two "sectors" were sampled from two half apples, cut into small pieces and cryo-ground in liquid nitrogen for $30 \mathrm{~s}$ with an IKA grinder. All the manipulations were done quickly to avoid ascorbic acid degradation. Samples of 3.5-4.0 g of frozen apple powder were poured into $20 \mathrm{ml}$ of a $10^{-2} \mathrm{M}$ aqueous solution of metaphosphoric acid previously degassed with helium. The samples were extracted for $10 \mathrm{~min}$ at $150 \mathrm{osc} / \mathrm{min}$ on a GFL 3020 rotative plate. The extracts were centrifuged for $5 \mathrm{~min}$ at $6000 \mathrm{rpm}$ and were then immediately analysed using HPLC.

\subsubsection{HPLC conditions}

The chromatographic separations were undertaken according to the International Federation of Fruit Juice Producers (IFFJP) standard method (1987), slightly modified: Nucleosil 100: $5 \mu \mathrm{m} \mathrm{C18}(250 \mathrm{~mm} \times 4.6 \mathrm{~mm})$ column from Macherey Nagel (Düren, Germany); Eluent: $0.01 \mathrm{M}$ ammonium acetate $(\mathrm{pH}=3.5)$ at $0.7 \mathrm{ml} / \mathrm{min}$; UV detection at $248 \mathrm{~nm}$. To verify response linearity, calibration curves $(0-200 \mu \mathrm{g}$ ascorbic acid/ml) were established with He degassed $10^{-2} \mathrm{MHPO}_{3}$ solutions of the pure molecule (Ref. A-5960 from Sigma, USA). Before and after each set of measurements, triplicate injections of a standard ascorbic acid solution (external standard) were systematically performed and the response factors calculated.

At the beginning of a working period, a concentrated solution of pure ascorbic acid $(1 \mathrm{mg} / \mathrm{ml})$ was injected twice to consume all residual oxygen which might present in the chromatographic system. Blanks $\left(10^{-2} \mathrm{M} \mathrm{HPO}_{3}\right.$ solution) were tested by chromatography for possible residues of ascorbic acid in the analytical system.

\subsection{Other analytical determinations}

The comparison of ascorbic acid content between 30 old and 5 commercial cvs was completed with the determination of other analytical parameters: DM, sugars, $\mathrm{pH}$ and MI. Sugar content was measured with a refractometer and expressed as Brix degree ( ${ }^{\circ}$ brix $)$. For DM, 3 g cryo-ground apples were dehydrated at $50^{\circ} \mathrm{C}$ to constant weight (Perring, 1989). 
The $\mathrm{pH}$ was determined using a penetration $\mathrm{pH}$-meter. The starch conversion chart for apples (Anonymous, 1995) was used to check the MI of fruit samples. The MI chart gives a scale from 1 (unripe) to 10 (ripe) and corresponds to the increasing discoloration of starch when fruit slices are soaked in KI solution. The starch conversion chart for apples was determined for commercial cvs and divided into two categories: radial and circular conversion. For the old cvs, there is no official reference by cv and therefore an MI intermediate between the two official references was considered.

\section{Results}

\subsection{Preliminary studies}

(a) The measured variability (relative standard deviation \%) of the analytical method measured on three different cvs (Grenadier $^{\mathrm{RGF}}$, Président Roulin ${ }^{\mathrm{RGF}}$ and Reinette Hernaut $^{\mathrm{RGF}}$ ) ranged from 0.5 to $1.5 \%$, with means of $8.0-24.0 \mathrm{mg} / 100 \mathrm{~g}$ of fresh matter (FM). It was therefore considered very reliable. Under these HPLC conditions, the ascorbic acid retention time was $3.0 \mathrm{~min}$ and the running time fixed at $6 \mathrm{~min}$ allowed for 10 determinations per hour.

(b) Descriptive statistics concerning the study of the cv "Jonagold" cv and the variability criteria are presented in Table 1. The data represent the mean of five fruit determinations except for the combination criteria sunny position/coloured $/ 85 \mathrm{~mm}$ (four fruits) and shady position/non-coloured/85 mm (three fruits).

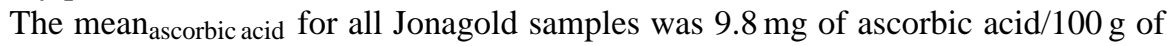
FM. A four-way analysis of variance (diameter, coloration, position, situation: tree1/ tree2), cross-mixed model was applied using the GLM procedure (SAS). This analysis indicated that there was no significant difference between fruits of 70 and $85 \mathrm{~mm}$ with regard to ascorbic acid content. For the coloration and position criteria, there were highly significant differences between coloured or non-coloured fruits $(P<0.0001)$ and between fruits sampled from the sunny and the shaded parts of the tree $(P=$ $0.0083)$. The interaction diameter $\times$ colour is significant $(P=0.0259)$ and as shown in Table 1, for coloured fruits there is a difference in ascorbic acid content between diameters but no difference for non-coloured fruits. These results suggest that for fruits from a sunny position, fruit size has to be as homogeneous as possible. In our case, fruit availability is a limiting factor because some cvs do not produce many fruits and the number of non-coloured fruits is very low.

Based on results of Jonagold coloured fruits sampled from sunny positions, we calculated the number of fruits to be analysed in order to detect a minimum difference between the ascorbic acid content of cvs. The results, summarised in Table 2, show the least significant differences in ascorbic acid content that can be detected between cvs (the calculation was based on mean ascorbic acid $=10 \mathrm{mg} / 100 \mathrm{~g} \mathrm{FM}$ ).

As an example, according to Table 2, for two sunny position/coloured fruits picked from one tree per cv, there is a significant difference between cvs if their ascorbic

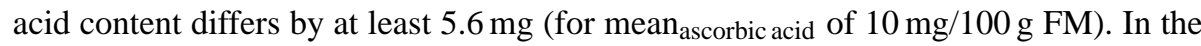
present case, the minimum difference between cvs was fixed at about $20 \%$ ( $2 \mathrm{mg}$ for a 
Table 1

Preliminary analysis: descriptive statistics of ascorbic acid content (mg/100 g of FM) for different criteria combination on cv Jonagold (mutant Dacosta)

\begin{tabular}{|c|c|c|c|c|c|c|c|}
\hline & \multicolumn{2}{|l|}{ Coloured } & \multirow[t]{2}{*}{ Sub-total $_{\text {ascorbic acid }}$} & \multicolumn{2}{|c|}{ Non-coloured } & \multirow[t]{2}{*}{ Sub-total $_{\text {ascorbic acid }}$} & \multirow[t]{2}{*}{ Total $_{\text {ascorbic acid }}$} \\
\hline & $70^{\mathrm{b}}$ & $85^{\mathrm{b}}$ & & $70^{\mathrm{b}}$ & $85^{\mathrm{b}}$ & & \\
\hline \multicolumn{8}{|l|}{ Sunny } \\
\hline Tree 2 & $9.0(1.65)$ & $10.0(2.52)$ & 9.5 & $5.8(0.69)$ & $6.5(1.40)$ & 6.2 & 7.9 \\
\hline Sub-total ${ }_{\text {ascorbic acid }}$ & 9.5 & 11.2 & 10.3 & 7.3 & 7.9 & 7.6 & 8.9 \\
\hline \multicolumn{8}{|l|}{ Shade } \\
\hline Tree 2 & $12.0(2.79)$ & $11.7(1.48)$ & 11.9 & $8.9(1.53)$ & $9.6(0.98)$ & 9.1 & 10.5 \\
\hline Sub-total ${ }_{\text {ascorbic acid }}$ & 11.4 & 12.6 & 12.0 & 9.6 & 8.7 & 9.2 & 10.6 \\
\hline Total $_{\text {ascorbic acid }}$ & 10.4 & 11.9 & 11.1 & 8.4 & 8.3 & 8.4 & 9.8 \\
\hline
\end{tabular}

a Mean and standard deviation of five fruits.

${ }^{\mathrm{b}}$ Diameter. 
Table 2

Calculations of ascorbic acid least significant differences (in $\mathrm{mg} / 100 \mathrm{~g}$ of FM) for different fruit sample sizes for sunny position/coloured fruits ${ }^{\mathrm{a}}$

\begin{tabular}{rlllllll}
\hline Number of trees & \multicolumn{2}{l}{ Fruit number/tree } \\
\cline { 2 - 8 } & 2 & 4 & 6 & 8 & 10 & 12 & 14 \\
\hline 1 & 5.6 & 4.4 & 3.9 & 3.6 & 3.5 & 3.3 & 3.3 \\
2 & 3.9 & 3.1 & 2.8 & 2.6 & 2.4 & 2.4 & 2.3 \\
3 & 3.2 & 2.5 & 2.2 & 2.1 & 2.0 & 1.9 & 1.9 \\
4 & 2.8 & 2.2 & 1.9 & 1.8 & 1.7 & 1.7 & 1.6 \\
5 & 2.5 & 2.0 & 1.7 & 1.6 & 1.5 & 1.5 & 1.5 \\
6 & 2.3 & 1.8 & 1.6 & 1.5 & 1.4 & 1.4 & 1.3 \\
7 & 2.1 & 1.7 & 1.5 & 1.4 & 1.3 & 1.3 & 1.2 \\
8 & 2.0 & 1.5 & 1.4 & 1.3 & 1.2 & 1.2 & 1.2 \\
9 & 1.9 & 1.5 & 1.3 & 1.2 & 1.2 & 1.1 & 1.1 \\
10 & 1.8 & 1.4 & 1.2 & 1.1 & 1.1 & 1.1 & 1.0 \\
\hline
\end{tabular}

${ }^{\mathrm{a}}$ Calculations based on a mean ascorbic acid of $10 \mathrm{mg} / 100 \mathrm{~g} \mathrm{FM} \mathrm{(cv} \mathrm{Jonagold,} \mathrm{mutant} \mathrm{Dacosta).}$

mean $_{\text {ascorbic acid }}$ of $10 \mathrm{mg} / 100 \mathrm{~g}$ FM). Ideally, one should take two fruits from each of three trees but in our orchard there are only two or three trees by cvs. From a practical point of view, a good compromise was made by taking a sample of 12 fruits per tree by cvs from two to three trees and allowing a difference of $1.9-2.4 \mathrm{mg}$ of ascorbic acid/100 g FM between cvs (Table 2).

(c) The results of the comparison between six old cvs are presented in Table 3. For Reinette de Waleffe and Court-Pendu Gris, there were only nine and seven fruits, respectively, corresponding to our sampling criteria. The one-way analysis of variance indicates that there were high significant differences between the studied cvs. The Student-Newmann and Keuls test highlighted three distinct groups: Grenadier ${ }^{\text {RGF }}$ and Bramley's Seedling with the highest ascorbic acid concentrations ( mean $_{\text {ascorbic acid }}$ of 23.7 mg/100 g FM), Reinette de Blenheim ${ }^{\text {RGF }}$, Court-Pendu Gris and Reinette de Waleffe with a mean ${ }_{\text {ascorbicacid }}$ of $14 \mathrm{mg} / 100 \mathrm{~g}$, and Reinette Hernaut $^{\text {RGF }}$ with a mean $_{\text {ascorbic acid }}=8.7 \mathrm{mg}$ ascorbic acid $/ 100 \mathrm{~g}$ FM. The same grouping emerged in terms of total sugar content (Brix).

\subsection{Ascorbic acid content and other fruit quality indicative parameters of 30 old cvs}

For practical reasons of fruit availability, six fruits by cvs on two-three trees were analysed and we detected difference of 2.2-2.8 mg of ascorbic acid/100 g FM between cvs (Table 2). The results of the determinations of ascorbic acid concentrations, MI, DM, brix and $\mathrm{pH}$ in fresh apple are shown in Table 4 . The data represent the mean of six determinations. No fruits of cvs Grenadier ${ }^{\mathrm{RGF}}$ and Reinette Hernaut ${ }^{\mathrm{RGF}}$ were available for the main study. Therefore, it was not possible to compare the ranked cvs from one year to another. A comparison can only be done for cvs Reinette de Waleffe and Reinette de Blenheim ${ }^{\text {RGF }}$.

A careful examination of Table 4 led to the following observations:

(a) We observe a global mean ascorbic acid concentration of $14.2 \pm$ (S.D. $=6.2 \mathrm{mg}$ /

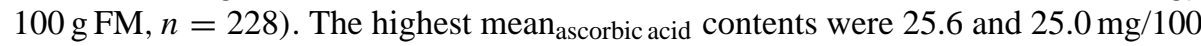


Table 3

Descriptive statistics (year 1998): mean and standard deviation for ascorbic acid contents (mg/100 g FM), brix ( ${ }^{\circ}$ brix) and pH of three 'RGF' cvs released by our Department and three other cvs from our germplasm; results of Student-Newman and Keuls test $(\alpha=0.05)$

\begin{tabular}{|c|c|c|c|c|}
\hline Cultivar & $N$ & Mean $_{\text {ascorbic acid }}$ & S.D.ascorbic acid & SNK \\
\hline \multicolumn{5}{|l|}{ Ascorbic acid } \\
\hline Grenadier $^{\text {RGF }}$ & 12 & 24.1 & 3.5 & $\mathrm{a}$ \\
\hline Bramley Seedlings & 12 & 23.3 & 3.2 & $\mathrm{a}$ \\
\hline Reinette de Blenheim ${ }^{\text {RGF }}$ & 12 & 14.6 & 1.6 & $\mathrm{~b}$ \\
\hline Court-Pendu Gris & 7 & 13.8 & 1.2 & $\mathrm{~b}$ \\
\hline Reinette de Waleffe & 9 & 13.3 & 1.7 & $\mathrm{~b}$ \\
\hline \multirow[t]{2}{*}{ Reinette Hernaut $^{\mathrm{RGF}}$} & 12 & 8.7 & 1.3 & $\mathrm{c}$ \\
\hline & & Mean $_{\text {brix }}$ & S.D.brix & \\
\hline \multicolumn{5}{|l|}{ Brix } \\
\hline Court-Pendu Gris & 6 & 19.0 & 1.9 & a \\
\hline Reinette de Waleffe & 9 & 17.7 & 1.1 & $\mathrm{a}$ \\
\hline Reinette de Blenheim ${ }^{\text {RGF }}$ & 11 & 14.4 & 1.4 & $\mathrm{~b}$ \\
\hline Grenadier ${ }^{R G F}$ & 11 & 13.1 & 0.4 & $\mathrm{bc}$ \\
\hline Reinette Hernaut ${ }^{\text {RGF }}$ & 12 & 12.5 & 0.5 & $\mathrm{c}$ \\
\hline \multirow[t]{2}{*}{ Bramley Seedlings } & 11 & 12.2 & 0.7 & $\mathrm{c}$ \\
\hline & & $\operatorname{Mean}_{\mathrm{pH}}$ & S.D.pH & \\
\hline \multicolumn{5}{|l|}{$\mathrm{pH}$} \\
\hline Reinette de Blenheim ${ }^{\text {RGF }}$ & 12 & 3.7 & 0.1 & a \\
\hline Court-Pendu Gris & 7 & 3.7 & 0.1 & $a b$ \\
\hline Reinette Hernaut ${ }^{\text {RGF }}$ & 12 & 3.6 & 0.1 & bc \\
\hline Reinette de Waleffe & 9 & 3.5 & 0.1 & $\mathrm{~cd}$ \\
\hline Grenadier $^{\mathrm{RGF}}$ & 12 & 3.4 & 0.1 & $\mathrm{~d}$ \\
\hline Bramley Seedlings & 12 & 3.2 & 0.1 & $\mathrm{~b}$ \\
\hline
\end{tabular}

FM, respectively, for cvs Transparente de Croncels and Bramley's Seedling (set 1). Reinette des Capucins (sets 1 and 2), Reinette Libotte and Reinette de Waleffe have more than $20 \mathrm{mg} / 100 \mathrm{FM}$.

(b) Gala, La Paix ${ }^{\mathrm{RGF}}$, Reinette Etoilée (sets 1 and 2), Radoux ${ }^{\mathrm{RGF}}$ and Elstar have the lowest ascorbic acid content.

(c) The results obtained for Calville Blanc d'Hiver ( mean $_{\text {ascorbic acid }}$ of $17.8 \mathrm{mg} / 100 \mathrm{~g} \mathrm{FM}$ ) highlighted the difficulty in making meaningful comparisons with data in the literature. Indeed, for the cvs studied here, only scarce "old" data are available. Also, the titrimetic methods used formerly could lead to significant over-estimations of ascorbic acid concentrations. For example, Tavernier and Jacquin (1946), using diphenylamine titration, reported very high ascorbic acid concentrations (59 mg/100 g FM).

(d) For the cvs presented twice (2 sets of 6 fruits), it is interesting to note that one-way variance analyses revealed no significant differences for Reinette des Capucins and Reinette Etoilée for MI and ascorbic acid. In contrast, for Bramley's Seedling, the significantly different MI corresponds to a significantly different ascorbic acid level.

(e) The MI values cover all the maturity stages: with a value of 10 , fruits of the Gala cv were very ripe, while those of Court-Pendu Rose were still green $(\mathrm{MI}=2)$ at the sampling 
Table 4

Ascorbic acid contents, MI, DM, brix and pH of 30 old apple cvs selected from our apple germplasm compared to five commercial $(*)$ apple $\mathrm{cvs}^{\mathrm{a}}$

\begin{tabular}{|c|c|c|c|c|c|}
\hline Cultivar & $\begin{array}{l}\text { Ascorbic acid } \\
(\mathrm{mg} / 100 \mathrm{~g})\end{array}$ & MI & $\mathrm{DM}(\mathrm{g} / 100 \mathrm{~g})$ & Brix & $\mathrm{pH}$ \\
\hline Transparente de Croncels & $25.6(3.1)$ & $6.7(1.0)$ & $19.3(1.1)$ & $14.2(1.3)$ & $3.35(0.09)$ \\
\hline Bramley's seedling (set 1) & $25.0(5.5)$ & $7.1(1.5)$ & $18.9(3.1)$ & $13.5(0.6)$ & $3.18(0.07)$ \\
\hline Reinette des Capucins (set 1) & $24.6(6.0)$ & $5.0(1.1)$ & $19.7(2.5)$ & $14.6(0.8)$ & $3.42(0.04)$ \\
\hline Reinette des Capucins (set 2) & $22.9(2.9)$ & $5.0(0.9)$ & $19.5(0.9)$ & $13.9(1.0)$ & $3.07(0.10)$ \\
\hline Reinette Libotte & $21.7(1.5)$ & $6.0(0.0)$ & $21.7(0.5)$ & $15.9(1.2)$ & $3.40(0.05)$ \\
\hline Reinette de Waleffe & $20.6(1.2)$ & $4.7(0.5)$ & $19.7(1.1)$ & $14.3(0.9)$ & $3.36(0.06)$ \\
\hline Court-Pendu Rose & $19.4(3.8)$ & $2.0(0.0)$ & $22.0(1.0)$ & $14.2(0.8)$ & $3.35(0.06)$ \\
\hline Joseph Musch RGF & $18.6(4.2)$ & $6.2(0.7)$ & $20.1(0.6)$ & $14.5(0.3)$ & $3.45(0.07)$ \\
\hline Reinette Descardre & $18.6(3.8)$ & $6.8(1.0)$ & $19.8(1.2)$ & $14.5(0.9)$ & $3.40(0.09)$ \\
\hline Calville Blanc d'Hiver & $17.8(3.7)$ & $5.1(1.2)$ & $17.1(0.8)$ & $12.0(0.9)$ & $3.41(0.05)$ \\
\hline Reinette du Mans & $17.7(3.1)$ & $3.8(0.4)$ & $20.3(0.5)$ & $13.9(0.3)$ & $3.58(0.06)$ \\
\hline Bramley's seedling (set 2) & $17.5(1.2)$ & $9.3(0.5)$ & $14.3(0.4)$ & $12.1(0.7)$ & $2.90(0.04)$ \\
\hline Peasgood non such & $16.9(2.2)$ & $7.8(0.4)$ & $18.0(0.9)$ & $13.7(0.4)$ & $3.50(0.08)$ \\
\hline Citron d'Hiver & $16.5(1.3)$ & $3.7(0.5)$ & $17.4(0.3)$ & $13.0(0.7)$ & $3.22(0.06)$ \\
\hline Reinette Ananas & $16.0(3.6)$ & $6.3(0.8)$ & $17.5(0.8)$ & $13.8(0.5)$ & $3.47(0.06)$ \\
\hline Président Van Dievoet ${ }^{R G F}$ & $16.0(2.3)$ & $5.2(0.9)$ & $17.0(0.5)$ & $12.3(0.2)$ & $3.29(0.05)$ \\
\hline Reinette César & $14.8(3.0)$ & $5.5(0.8)$ & $22.4(2.1)$ & $16.8(2.1)$ & $3.40(0.04)$ \\
\hline Reinette du Canada Blanc & $13.9(1.7)$ & $5.2(0.7)$ & $18.7(0.7)$ & $13.8(0.5)$ & $3.44(0.05)$ \\
\hline Reinette de Blenheim ${ }^{\text {RGF }}$ & $13.8(1.2)$ & $5.3(0.5)$ & $18.6(2.0)$ & $12.3(1.6)$ & $3.38(0.06)$ \\
\hline Reinette de France & $13.1(0.9)$ & $5.0(0.6)$ & $20.7(0.4)$ & $15.6(0.4)$ & $3.33(0.06)$ \\
\hline Président Roulin ${ }^{\mathrm{RGF}}$ & $12.8(4.2)$ & $8.2(1.5)$ & $15.8(1.6)$ & $12.0(1.2)$ & $3.16(0.10)$ \\
\hline Godivert $^{\mathrm{RGF}}$ & $12.7(2.6)$ & $9.2(0.9)$ & $16.3(0.7)$ & $12.3(1.1)$ & $3.38(0.09)$ \\
\hline Gris Braibant ${ }^{R G F}$ & $12.4(4.4)$ & $8.0(1.4)$ & $20.6(2.1)$ & $15.6(0.9)$ & $3.48(0.14)$ \\
\hline Schone van Boskoop* & $12.3(1.5)$ & $9.3(0.8)$ & $17.0(0.5)$ & $13.2(0.5)$ & $3.31(0.02)$ \\
\hline Jonagold ${ }^{*}$ & $11.9(0.5)$ & $8.3(1.0)$ & $17.0(0.4)$ & $13.8(0.6)$ & $3.70(0.19)$ \\
\hline Reinette de Chênée & $11.4(3.3)$ & $7.3(2.0)$ & $19.5(1.4)$ & $15.3(1.7)$ & $3.33(0.17)$ \\
\hline Golden Delicious* & $11.4(1.6)$ & $7.7(1.2)$ & $17.8(0.9)$ & $13.8(0.9)$ & $3.65(0.06)$ \\
\hline Reinette Evagil ${ }^{\text {RGF }}$ & $10.8(3.9)$ & $7.0(1.5)$ & $\mathrm{ND}^{\mathrm{b}}$ & $13.9(0.9)$ & $3.35(0.15)$ \\
\hline Reinette Clochard & $10.8(1.0)$ & $5.0(0.0)$ & $19.1(0.7)$ & $12.9(0.8)$ & $3.44(0.03)$ \\
\hline Cwastresse Double ${ }^{\text {RGF }}$ & $10.2(1.5)$ & $5.6(0.8)$ & $18.4(0.9)$ & $13.5(1.4)$ & $3.36(0.06)$ \\
\hline Belle-Fleur large Mouche & $9.8(1.2)$ & $6.8(0.7)$ & $17.9(0.5)$ & $13.2(0.8)$ & $3.56(0.09)$ \\
\hline Belle et Bonne & $9.3(1.4)$ & $5.1(0.4)$ & ND & $12.2(0.7)$ & $3.51(0.04)$ \\
\hline Elstar* & $6.4(1.5)$ & $7.8(1.5)$ & $17.0(1.4)$ & $13.7(1.1)$ & $3.60(0.12)$ \\
\hline Radoux $^{\text {RGF }}$ & $6.4(1.3)$ & $8.3(1.2)$ & $16.2(1.0)$ & $11.9(0.6)$ & $3.41(0.07)$ \\
\hline Reinette Etoilée (set 2) & $6.3(0.9)$ & $7.7(0.8)$ & $19.0(1.3)$ & $15.2(1.2)$ & $3.27(0.09)$ \\
\hline Reinette Etoilée (set 1) & $6.2(1.4)$ & $7.0(1.1)$ & $18.7(2.2)$ & $15.2(1.6)$ & $3.51(0.16)$ \\
\hline La Paix ${ }^{R G F}$ & $5.8(1.4)$ & $8.3(0.5)$ & $16.7(0.7)$ & $12.6(0.7)$ & $3.79(0.21)$ \\
\hline Gala* & $2.9(0.9)$ & $10.0(0.0)$ & $15.6(0.5)$ & $12.9(1.8)$ & $4.08(0.20)$ \\
\hline Global mean & $14.2(6.2)$ & & & & \\
\hline
\end{tabular}

\footnotetext{
${ }^{a}$ Data ordered by descending value of ascorbic acid contents; mean and standard deviation of six sunny coloured fruits; total number of fruits $=228$ for the global mean (year 1999).

b Not done.
} 
date. The MI of all other cvs ranged between these two extreme values, indicating different degrees of ripeness. This observation corresponds to values recorded for DM, total sugar content and $\mathrm{pH}$ which varied between 14.3 and $22.4 \%, 11.9$ and $16.8 \%$ and 2.9 and $4.8 \%$, respectively. The comparison of the common cvs from Tables 3 and 4 show that from one year to another, Reinette de Blenheim ${ }^{\text {RGF }}$ has, respectively, 14.6 and $13.8 \mathrm{mg} / 100 \mathrm{~g}$ FM but for Reinette de Waleffe the variation is higher with 13.3 and $20.6 \mathrm{mg} / 100 \mathrm{~g}$ FM, respectively.

A study of correlations established between all variables showed that there were significant correlations between ascorbic acid and MI, ascorbic acid and DM, ascorbic acid and $\mathrm{pH}$, with $r$ values of $0.47,0.45,-0.45$, respectively. MI and DM were negatively correlated $(r=$ $-0.53)$. These results suggest a possible link between qualitative properties and ascorbic acid content. Nevertheless, a more complete study is necessary to validate this assumption.

\section{Discussion and conclusions}

This study shows that the comparison of ascorbic acid levels in apple cvs is a difficult challenge because, even using an effective analytical method, one must take into account other influential "biological" factors linked to fruit ripeness such as colour, position on the tree and diameter linked to colour. To detect a $20 \%$ difference in ascorbic acid concentration between two cvs, it is necessary to make at least six repetitions on different coloured sunny position fruits with a known MI. The issue of sampling heterogenity is of major importance here. Heterogeneity between orchards and years was not taken into account in this study.

The cvs with the highest ascorbic acid content were Transparente de Croncels, Bramley's Seedling, Grenadier ${ }^{\mathrm{RGF}}$, Reinette des Capucins, Reinette Libotte and Reinette de Waleffe, with more than $20 \mathrm{mg} / 100 \mathrm{~g}$ FM. This level is high compared with those of the commercial cvs investigated: Jonagold (11.9 mg/100 g FM), Golden Delicious (11.4 mg/100 g FM), Elstar $(6.4 \mathrm{mg} / 100 \mathrm{~g} \mathrm{FM})$ and Gala $(2.9 \mathrm{mg} / 100 \mathrm{~g} \mathrm{FM})$. Note that the Gala fruits were very ripe (all fruits had an MI of 10). MI is really a crucial "limiting" factor as it is not easy to evaluate objectively. It is to notice that the ascorbic acid content of Reinette de Waleffe, was of $13.3 \mathrm{mg} / 100 \mathrm{~g}$ FM during the preliminary analysis due probably to both factors, year and sampling method; therefore, complementary analyses are necessary for this cv.

It is important to highlight this higher ascorbic acid content in comparison with commercial cvs (Gala, Elstar and to some extent Golden Delicious and Jonagold). Such an important nutritional property can be used as a way of direct evaluation for those particular cvs if they also possess other interesting agronomic characters related to a reasonable level of disease resistance. It is therefore very important to carry out an evaluation of apple genetic resources collections in order to highlight their potential value for nurseries, fruit growers and processing industries, and such cvs should be incorporated as parents in breeding programmes with the specific aim of improving the nutritional properties of apple cvs.

The final table presented, where cvs are ranked, has to be taken with some caution due to the variability of ascorbic acid between years, especially in relation to MI. Confirmation studies should be done to better quantify the variability during years that will allow to give a more precise ranked cvs table. 
Nevertheless, this study enabled us to identify apple cvs with interesting agronomic and nutritional characteristics that had never been studied previously and suggest new ways of evaluating our genetic resources.

\section{Acknowledgements}

The authors gratefully acknowledge the General Directorate for Technology, Research and Energy of the Ministry of the Walloon Region of Belgium for their financial support, as well as Mr. D. Trisman for his valuable and helpful technical support.

\section{References}

Anonymous, 1995. Le point sur le test amidon pour l'aide à la décision de récolte. Code de régression de l'amidon des pommes (EUROFRU). Info CTIFL, p. 114.

Barthelemy, J.P., 1996. Le dosage de l'acide ascorbique par chromatographie liquide haute performance. Revue bibliographique (1986-1992). Analusis 24 (4), 95-103.

Davies, M.B., Austin, J., Partridge, D.A., 1991. Vitamin C: Its Chemistry and Biochemistry. Cambridge Royal Society of Chemistry, $154 \mathrm{pp}$.

Delaporte, N., 1971. Influence de la teneur en oxygène des atmosphères sur le taux d'acide ascorbique des pommes au cours de leur conservation. Lebensm-Wiss Technol. 4, 106-112.

Delmotte, C., 1984. La teneur des pommes en vitamine C et les possibilités de son dosage: revue bibliographique. Bull. Rech. Agron. Gembloux 19 (3-4), 269-284.

Fisher, C., 1999. Ergebnisse der Apfle Züchtung in Dresden-Pillnitz. Berlin. Erwerbsobstbau 41, 65-74.

Lateur, M., 2000. Fruit tree genetic resources and Integrated Fruit Production. In: Proceedings of the International Conference on Integrated Fruit Production. In: Müller, P., Verheyden, W. (Eds.), Acta Horticulturae, vol. 525, pp. 317-323.

Lateur, M., Populer, C., 1996. Evaluation and identification methods used for apple genetic resources at the State Plant Pathology Station in Gembloux, Belgium. In: Case, H.J. (Ed.), European Malus Germplasm. ECP/GR \& IPGRI, Rome, pp. 78-87.

Machlin, L.J., 1991. Handbook of Vitamins. Dekker, New York, 595 pp.

Mapson, L.W., 1970. Vitamins in fruits. In: Hulme, A.C. (Ed.), The Biochemistry of Fruits and Their Products, vol. 1. Academic Press, London, pp. 369-383.

Perring, M.A., 1989. Changes in dry matter concentration gradient in stored apples. J. Sci. Food Agric. 46, 439-449.

Populer, C., Lateur, M., Wagemans, C., 1998. Ressources génétiques et résistance aux maladies des arbres fruitiers. Biotechnol. Agron. Soc. Environ. 2 (1), 46-58.

Schuphan, W., 1956. Valeur nutritive des fruits en rapport avec l'alimentation humaine. In: Soc. Pomol. France. C.R. Congr. Pomol. Int., 87e Sess. Namur, Belgium, pp. 31-52.

Tavernier, J., Jacquin, P., 1946. La vitamine C dans la pomme et les produits dérivés de la pomme. Bull. Assoc. Chim. 3-4, 111-128.

Trzcinski, T., Bouckoms, M.A., 1973. Brève observation sur la richesse en vitamine C de quatre variétés de pommes en 1972. Le Fruit Belge 361, 73-76.

Trzcinski, T., Vandermeir, M.A., 1974. Observations sur la richesse en vitamine C des pommes Cox's orange pippin et Golden Delicious récoltées en 1973. Le Fruit Belge 367, 204-208.

Ulrich, R., Delaporte, N., 1970. L'acide ascorbique dans les fruits conservés par le froid, dans l'air et en atmosphère contrôlée. Ann. Nutr. Alim. 24 (3), B287-B325.

Wimalasiri, P., Wills, R., 1983. Simultaneous analysis of ascorbic acid and dehydroascorbic acid in fruit and vegetables by high-performance liquid chromatography. J. Chromatogr. 256, 368-371. 